\title{
Reputation as a Key Resource for Market Success in the Banking Sector
}

\author{
Berislava Starešinić \\ Privredna banka d.d., Croatia \\ Mislav Ante Omazić \\ Faculty of Economics and Business, University of Zagreb, Croatia \\ Ana Aleksić \\ Faculty of Economics and Business, University of Zagreb, Croatia
}

\begin{abstract}
Acknowledging the importance and role of corporate reputation as a unique intangible and specific organizational resource, in this paper, we analyze its role and importance for the market success of contemporary banks. Furthermore, the paper provides an overview of the existing research regarding bank reputation in the Republic of Croatia. As corporate social responsibility aspect of a business is one of the most widely studied aspects of corporate reputation, we investigate the corporate social responsibility practice of two major banks in Croatia. By using publicly available data, we analyse the internal and external dimensions of their CSR and their relation to a bank's reputation.
\end{abstract}

Keywords: reputation, bank, banking sector JEL classification: L14, G21

\section{Introduction}

In times of uncertain and rapidly changing environment, financial institutions, and banks especially, are not exempt from fierce competition. As Carlucci et al. (2018) emphasize the 21 st century has been characterized by greater business diversification of the banking industry and it is estimated that in the coming years the banking sector will become even more complex. Thus, trying to position themselves on the market, banks are in constant search for new sources of competitiveness that can ensure market success in the banking sector. Corporate reputation has been recognized as a unique and valuable resource, that is difficult for competitors to imitate, and research has indicated that reputation can be directly linked with the survival of financial institutions, their accounting performance and negatively related to advantage and riskiness profiles (e.g. Bushman et al., 2012; Ruiz et al., 2016; Dell'Atti et. al., 2017). In the banking industry, despite the relevance of trust and relationships with stakeholders, the reputation and reputational risk research areas have until recently remained under-explored (Trotta et al., 2016). Ruiz et al. (2014, p. 260) wrote regarding corporate reputation, the problems derived from the complex and intangible nature of reputation are perfectly known, making it very hard to perform a conceptual delimitation, characterization, and measurement.

In line with previous, the objective of this paper is to provide a theoretical overview of the role and importance of corporate reputation in general, and more specifically, its importance for contemporary banks. Furthermore, the paper provides an overview of the existing research regarding bank reputation in the Republic of Croatia. As corporate social responsibility (CSR) aspect of a business is one of the most widely 
studied aspects of corporate reputation and studies (e.g., Saeidi et al., 2015) indicate it is one of the most important instruments in developing and advancing reputation, we investigate CSR practice of two major banks in Croatia. By using publicly available data, we analyze the internal and external dimensions of their CSR and their relation to a bank's reputation.

\section{Corporate reputation and major theories of reputation}

Reputation should present intangible organizational resource, that follows organization in all of its intra and inter-organizational relationships. It presents a fundamental bond between different organizational stakeholders. If properly used, integrated, and coordinated through organization and its processes, reputation as a resource can become a significant organizational capability (Carmeli and Cohen, 2001).

Among others, reputation is an organizational capability to satisfy needs of customers and other stakeholders, and if in its early stages, the organization uses all of its resources, without having a strong connection with suppliers and customers, it is less likely it will survive. Many newly founded organizations do not survive on the market for more than a year, and lack of reputation and trust from stakeholders are considered to be one of the sources of their failure (Nicolò, 2015). One is for sure; it is a challenge to grasp its core contents or to explain what specific value is associated with achieving a good reputation (Helm, 2011).

Fombrun et al. (1997) are the first trying to systematize the nomenclature of corporate reputation, starting from corporate identity and image. On the one hand, corporate identity is a reflection of employees and managers' perceptions of the company and includes the key characteristics that differentiate the company from the competition, continually linking past, present and future results. On the other hand, corporate image is a reflection of the perception of interest-influential groups outside the company and is considered as a consequence of public relations, marketing and other organizational processes that shape people's perception of the company (image). The company may try to modernize its corporate image, but the final result will be influenced by publicity, regulation, industry characteristics, and other external factors. According to Fombrun (2001), a new comprehensive and amended definition of reputation is used, that includes economic value (reputation capital), image (representation), and quality assessment of the company. The following table provides an overview of the definitions and main attributions of reputation, as seen by several authors. 
Table 1

Overview of the Definitions and Attributes of Reputation

\begin{tabular}{|c|c|c|}
\hline Author(s) & Definition & Attributes \\
\hline $\begin{array}{l}\text { Fombrun, 1996; Mahon, 2002; } \\
\text { Rindova et al., } 2010\end{array}$ & $\begin{array}{l}\text { Business activities to date and } \\
\text { the potential to generate future } \\
\text { benefits for its stakeholders }\end{array}$ & Reputation as intangible asset. \\
\hline $\begin{array}{l}\text { Grunig et al., 2002; Rindova et } \\
\text { al., 1999; Schultz et al., 2006; } \\
\text { Yang et al., } 2005\end{array}$ & $\begin{array}{l}\text { The range of interconnected } \\
\text { complex activities of a company } \\
\text { that builds a reputation. }\end{array}$ & $\begin{array}{l}\text { Reputation represents a large } \\
\text { number of different company } \\
\text { activities. }\end{array}$ \\
\hline $\begin{array}{l}\text { Fombrun et al., 2004; Shapiro, } \\
\text { 1983; Schultz et al., } 2006\end{array}$ & $\begin{array}{l}\text { There is no universal framework } \\
\text { of reputation. The reputation } \\
\text { varies depending on the } \\
\text { characteristics of the company } \\
\text { and its stakeholders. }\end{array}$ & $\begin{array}{l}\text { The concept of reputation is } \\
\text { inseparable from the context } \\
\text { of a competitive offer. }\end{array}$ \\
\hline $\begin{array}{l}\text { Golin, 2003; Simcic Brønn, 2007; } \\
\text { Stigler, 1962; Trček, 2018; Zabala } \\
\text { et al., } 2005\end{array}$ & $\begin{array}{l}\text { Trust as a sociological construct } \\
\text { and the foundation of long-term } \\
\text { success. Trust is the basis of } \\
\text { competitive advantage, and } \\
\text { competitive advantage is a } \\
\text { source of reputation. }\end{array}$ & $\begin{array}{l}\text { Reputation is a mechanism } \\
\text { through which stakeholders } \\
\text { that aren't often sufficiently } \\
\text { aware of the overall activities } \\
\text { of the company are deciding } \\
\text { about the trust of the } \\
\text { company. }\end{array}$ \\
\hline $\begin{array}{l}\text { Doorley et al., 2006; Jones, 1995; } \\
\text { Phillips, 2006; Simcic Brønn, } 2007\end{array}$ & $\begin{array}{l}\text { Enterprise activities and their } \\
\text { communication for the purpose } \\
\text { of building a relationship. }\end{array}$ & $\begin{array}{l}\text { Reputation is communication } \\
\text { and relational capital. }\end{array}$ \\
\hline $\begin{array}{l}\text { Brammer et al., 2006; Brown et } \\
\text { al., 2006; Corley et al., 2006; } \\
\text { Fombrun, } 1996\end{array}$ & $\begin{array}{l}\text { Reputation is difficult to } \\
\text { manipulate by the company. It is } \\
\text { the result of a large number of } \\
\text { factors based on perception. }\end{array}$ & $\begin{array}{l}\text { ation is a social construct } \\
\text { esult of perception. }\end{array}$ \\
\hline $\begin{array}{l}\text { Flanagan et al., 2005; Fombrun, } \\
1996\end{array}$ & $\begin{array}{l}\text { The result of the perception of all } \\
\text { stakeholders, internal and } \\
\text { external. }\end{array}$ & $\begin{array}{l}\text { Reputation is a mutual } \\
\text { perception of all stakeholders. }\end{array}$ \\
\hline $\begin{array}{l}\text { Brown et al., 1997; Fombrun, } \\
\text { 1996; Lange et al., 2011; Wartick, } \\
2002\end{array}$ & $\begin{array}{l}\text { Enterprises can be compared } \\
\text { based on their reputation. } \\
\text { Longitudinal comparisons can } \\
\text { be made and calculate industry } \\
\text { or sector average. }\end{array}$ & $\begin{array}{l}\text { Reputation is comparable } \\
\text { construct. }\end{array}$ \\
\hline $\begin{array}{l}\text { Brown et al., 2006; Rhee et al., } \\
\text { 2006; Yunfang, } 2007\end{array}$ & $\begin{array}{l}\text { Ultimate corporate reputation as } \\
\text { a result of historical activity. It is } \\
\text { relative and comparable and } \\
\text { can be positive and negative. }\end{array}$ & $\begin{array}{l}\text { Reputation has a binary } \\
\text { character: positive or } \\
\text { negative. }\end{array}$ \\
\hline $\begin{array}{l}\text { Gray et al., 1998; Rindova, 1997; } \\
\text { Roberts et al., } 2002\end{array}$ & $\begin{array}{l}\text { Reputation represents a long- } \\
\text { term perception of the } \\
\text { company and a reflection of its } \\
\text { core values. }\end{array}$ & Reputation is not volatile. \\
\hline $\begin{array}{l}\text { Doorley et al., 2015; Nurn et al., } \\
2010\end{array}$ & $\begin{array}{l}\text { Corporations and other } \\
\text { organizations develop } \\
\text { reputational capital that helps } \\
\text { them build relationships and } \\
\text { grow their organizations. }\end{array}$ & $\begin{array}{l}\text { Reputation has both intangible } \\
\text { and tangible benefits. }\end{array}$ \\
\hline
\end{tabular}

Source: Authors' work according to Grgić (2012)

Barnett et al. (2006) have researched literature to provide an overview of the definitions of corporative reputation. Based on the analysis of 47 statements, they specify three groups of definitions of corporative reputation: reputation as recognition reputation as the assessment of the company and reputation as economic value. The recognition implies the use of language that symbolizes how the company has been recognized by the interest groups, but without a direct positive or negative evaluation. The definitions that belong to the assessment group define the company's status with estimation, where a sort of an attractive side to the company is implied. And finally, 
the definition of a reputation as asset refers to intangible, i.e. economic value of the company, where the last group of the definitions primarily deals with the implications of reputation.

Grgić (2012) states that there are three methods for measuring a company's reputation listed in the literature: the evaluation of the specialized magazines, the reputation quotient, and the Corporate Personality Scale. A common approach to measuring reputation is to take comparative measures against the similar organization (Doorley et al., 2015) The first specialized magazine that measured the reputation of companies was Fortune in 1983 with its AMAC scale (America's most admired companies). There are other specialized magazines that have measured the reputation of companies presented in Table 2.

Table 2

List of most influential magazines and published list of companies by their reputation

\begin{tabular}{|c|c|}
\hline Magazine & Published list \\
\hline Manager Magazine (MM) & $\begin{array}{l}\text { since } 1987 \text { has been publishing top } 100 \text { largest German } \\
\text { manufacturing and service companies }\end{array}$ \\
\hline Management Today (MT) & $\begin{array}{l}\text { since } 1991 \text { has been publishing a counterpart of the Fortune } \\
\text { magazine for the most prestigious British companies }\end{array}$ \\
\hline Asian Busines (AB) & $\begin{array}{l}\text { since } 1992 \text { has been publishing a counterpart of the Fortune } \\
\text { magazl ine for the most prestigious Asian companies }\end{array}$ \\
\hline $\begin{array}{l}\text { Faar Eastern Economics } \\
\text { Review (FEER) }\end{array}$ & $\begin{array}{l}\text { since } 1993 \text { has been publishing a list of the leading Asian } \\
\text { companies (ALC) }\end{array}$ \\
\hline Financial Times (FT) & $\begin{array}{l}\text { since } 1994 \text { has been publishing a list of the most prestigious } \\
\text { European companies; the list has later become global }\end{array}$ \\
\hline Industry Week (IW) & $\begin{array}{l}\text { since } 1997 \text { has been publishing a list of the best managed } \\
\text { companies as the result of a vote and multiple nominations }\end{array}$ \\
\hline Fortune GMAC & $\begin{array}{l}\text { since } 1997 \text { has been publishing a list of the most prestigious } \\
\text { companies globally }\end{array}$ \\
\hline
\end{tabular}

Source: Authors' work

As quoted in Grgić (2012), according to Fombrun, the rank on a reputation list differs depending on the criteria of the evaluation, but the elements that are evaluated are mostly as follows: financial indicators, product and service quality, relationship with the employees, the role within the community, environmental protection and business ethics. To expand the activities of the interest groups outside the management according to the Fortune AMAC, 1999. Reputation Institute (2018) and The Harris Poll (2018) construed the reputation quotient that includes the costumers that buy goods and services, the employees, and the investors. The instrument has been tested by 300,000 people in Australia, USA, and Europe. Personality scale as a method for measuring reputation accentuates the role of customers and employees and includes seven dimensions: comfort, initiative, expertise, elegance, consideration, masculinity and relaxation (Davies et al., 2003). Comfort is highlighted as the most important dimension, and it reflects the trust and social responsibility of the company as the key dimension of personality.

Divergent behaviour and social expectations represent the basic source of risk for the company's reputation. As quoted in Grgić (2012), Dowling et al. list four basic categories of reputation: management, environmental protection, employees' rights, and product safety. Lee et al. (2009) think that these categories are especially important for those companies being connected with socially responsible business, which creates and keeps the trust between them and the interest groups, and 
Ultimately influences the withdrawal of the capital, the development of the network of the business partners and the increase of sales. Rindova et al. (2005) identify two distinct (but interrelated) dimensions of organizational reputation, perceived quality, and prominence, which have different antecedents. In their model, certifications provided by institutional intermediaries have a strong influence on a firm's prominence.

On the sample of 52 research papers and 33,878 observations, Orlitzky et al. (2003) tested the connection of social indicators of business activities and financial performances. The results of their research suggest that social responsibility of a company (environmental care to a lesser extent) has a significant influence on financial performance. Also, it is important to note that socially responsible conduct has more influence on the accounting indicators and less on the market indicators. Furthermore, regarding the financial performances of companies, the authors have recognized the very reputation as the most significant element. On the other hand, McWilliams et al. (2001) state that socially responsible business reflects the company's size, the level of diversification, investment in R\&D and promotion, cooperation with the public sector, level of income, market conditions and the position in the life cycle of the industry. They conclude that there is an ideal level of socially responsible business that can be calculated as the ratio of benefit and costs, and consequently as a neutral relationship between social responsibility and financial performances. In addition, based on the theory of marking, Fombrun et al. (1990), being the pioneers of corporative reputation, distinguish two types of reputation: CA (Corporative ability in production) \& CSR (Corporate social responsibility). Based on the research results, they state how the reputation of a company influences the perception of the quality of new and the existing products, CA \& CSR can have a different influence, and the products of companies that have issues with reputation do not necessarily have a negative response.

One of the most recent researches in the field of corporative reputation, like that of Saeidi et al. (2015), suggests that previous research of the direct link between socially responsible business and financial indicators remains insufficiently confirmed and imprecise. They think that the cause for this lies in the series of mediation effects between socially responsible business and financial indicators of the company and list: sustainable competitiveness, company's reputation, and client satisfaction. On the sample of 205 companies, they have confirmed the mediation role of socially responsible business and financial indicators in the case of reputation and competitive advantage, while client satisfaction turned out to be an added bonus and the result of the previously mentioned mediators.

loannou et al. (2015) studied the influence of corporative reputation on investment recommendations of the analysts and it showed that at the beginning of the 1990s, high level of socially responsible business had a negative influence on the assessment of the future financial indicators, but over time, this influence has changed and, today, it entails a more optimistic prognosis.

Chernev et al. (2015) confirm that socially responsible business, though not connected with the basic business activities of a company, can have a positive influence on the perception of the quality of its products. This occurs even when consumers can see and test the product.

It can be concluded that corporative reputation is an important intangible asset of a company that can be linked to the most important financial indicators and longterm sustainable competitive advantage. Also, socially responsible business is, in fact, one of most frequently examined factors of corporative reputation, and the findings 
show that socially responsible business can and should be a valuable instrument of strategic management in development and advancement of company's reputation.

\section{Role and antecedents of corporate reputation for banks}

Taking care of its reputation is in the financial institution's DNA. According to Trotta et al. $(2016$, p. 6), the crucial role of reputation is self-evident in the banking and financial industries, as it is related both to the "raison d'être" of banks and the special nature of banking business in the context of contemporary financial intermediation theories. Banks are a dominant segment of the financial system and have an important role in the process of financial intermediation (Živko et al., 2013). Kasasbeh et al. (2017) emphasize its economic importance for national development has been a strong factor that motivated development and implementation of arrays of frameworks for their competitive advantage. Reputation is particularly important for banks and financial firms because the services they provide are intangible (Fombrun, 1996; Wang et al., 2003).

However, complexity and intangibility that is a common feature of most financial services generally make the identification of a clear source of competitive advantage a complex issue (Devlin et al., 1997). In that sense, it is not surprising that studies show that for banks the sources of their sustainable competitive advantage were found to be internally generated (e.g., Trotta et al., 2016; Redempta, 2008). For instance, Kasasbeh et al. (2017) found the quality of service or/and management, corporate social responsibility, strategy formulation, (electronic) marketing innovation and creativity, among others, were the factors influencing competitive advantage in the banking sector. Reputation was also found to be a significant factor in survival (Bushman et al., 2012). As Ruiz et al. (2016) state, the reason for this is the intangible nature of banking services that eventually makes them difficult to assess, and thus, higher importance is given to reputation. Trotta et al. (2012) additionally stress that financial operations are mainly based on trust, and thus, reputation is also critical.

Reputation reduces stakeholders' concerns and uncertainty about the quality of bank products and the value of future exchanges (Rindova et al., 2005). In times of crisis, especially, studies show that as regards to bank services purchasing decisions have been heavily influenced by bank reputations (Dell'Atti et al., 2017).

Research has also indicated that bank reputation is positively related to accounting performance and negatively related to leverage and riskiness profiles (e.g., Dell'Atti et al., 2017). Moreover, the reputation of banks that is unfavourable is negatively related to customer loyalty and their unwillingness to make comments or positive recommendations of products or services (Ruiz et al., 2014).

According to Shapiro (1983, as cited in Ruiz et al., 2014), quality of products and services is the key element that affects reputation. It is the prime contact between consumers and organizations, thus helps the organization to gain credibility. Wang et al. (2003) looked at service and product quality and their connection to the reputation of banks in China, concluding that quality of both service and products had a significant influence on bank reputation. Moreover, not only that it leads to higher reputation, but quality products and services improve retention of the existing customers, and attract new ones, increases financial performance and profitability (Roy et al., 2013).

Krzakiewicz et al. (2015) besides the quality of products and services, emphasize the behaviour of organizational members as antecedents of bank reputation. Based on their systematization of the existing research, Ruiz et al. (2016) define additional antecedents, recognizing six major antecedents that determine bank reputation: products/services, employer branding, reliability/financial strength, and corporate 
social responsibility as cognitive antecedents and satisfaction and trust as emotional antecedents.

\section{The reputation of banks in the Republic of Croatia}

Due to the turbulent history of business activities in the banking sector in the Republic of Croatia, because of national crises or the international financial crisis in 2008, bank reputation has been damaged. By 1991, the banking sector was marked with crediting discretionary clients, and consequently, out of 29 banks, 13 were declared insolvent. Although many banks were closed due to the insolvency, and the recovery was made from the national budget, bank activity has not much changed since. The inflation rate, as the consequence of discretionary consumption that was financed with the primary emission of funds on a monthly level, reached $25 \%$ in 1994 . The program for stabilization was executed in 1995, and after that, the prices remained stable for more than 20 years, but the economy, due to the initial exchange rate anchoring and lack of trust in the domestic currency, has kept a high level of euroization till today.

Furthermore, banking activities in the Republic of Croatia is characterized with numerous issues, some of which ended up in court (relationship lending, covering up the real creditworthiness of the clients, manipulations on financial markets, aggressive risk-taking, confiscating real estates). Banks have been sued for contracts from a clients point of view contained elements of harmful financial products, i.e. predatory elements. In many countries of Middle Europe, the issue of long-term loans with the currency clause, and in Croatia, especially the case of the Swiss franc has had the greatest negative reputation. Namely, lower interest rates for loans in Swiss francs attracted more people than those in Euros, so the clients were entering long-term contracts whose counter value of the annuity has considerably grown due to the consequential high volatility of Swiss franc.

Grgić (2012) observes that in conditions of strong competition, banks cannot build sustainable competitive advantage easily, and the orientation towards short-term optimization of the profit places the accent on tactical decisions. Besides the usual competencies, banks should develop a reputation that cannot be replicated quickly by the competition. So, creating and maintaining reputation becomes an important element of strategies adopted by the banks, and the clients assign more value to the service provided by the banks with a better reputation. As a company develops, its market value transforms from the initial value that is based on material asset towards the value dominated by an immaterial asset (social expectations, trust, and relations) - starting from the empirically confirmed concept of measuring reputation with the "reputation quotient" and the criticism by Wartick (2002) who suggests that the reputation of the afore-mentioned instrument is first and foremost the result of the perception of the general public that is not necessarily connected with the business activities of the bank. Grgić (2012) expands the model for relations of the companies with the influential groups that represent the bank's clients and distinguishes the total of 24 attributes and seven dimensions. The seven dimensions are an emotional experience, relations with the clients, product and service quality, vision and leadership, quality of the working environment, financial performance, and social responsibility. The research on the sample of the largest Croatian banks has indicated that the above-mentioned dimensions are significant for the reputation of the bank and have a positive effect on the perceived competitive advantage, apart from the aspect of vision and leadership that showed not to have a significant influence on reputation and competitiveness. The variables have given an explanation for $95 \%$ of reputation and $79 \%$ of the perceived competitiveness. It can be said that reputation 
is an intangible asset of the company and represents the basis for competitive advantage.

Sičenica (2001) sees the reputation of a bank as a reflection of the marketing principles and, in the long run, a sustainable approach being an indispensable element of the strategy of modern banking. The user as the long-term partner has to be able to influence the production, price, and distribution of the product, where informative and open communication appears as a tool for building trust. Also, Andaleeb et al. (1996) state that in less developed economies, user trust in bank products and services will be a reflection of trust in the organization and is not connected with the level of knowledge the very user possesses. Furthermore, although there is no consensus on the nature of their relation, trust in the bank can be linked to the aspect of socially responsible business. Certain researches (e.g. Kundid et al., 201 1; Ivić et al., 2013; Wu et al., 2013) suggest that there is a positive correlation between socially responsible business and profitability, but Balabanis et al. (1998) note that all aspects of socially responsible business do not have equal influence on the profitability of a bank and that decisions directed at protection of the environment can have negative impact on the business result. Nevertheless, if there is a high level of homogeneity of bank products and services on the market, due to the high level of competition, social responsibility can be an important factor in choosing a bank, no matter what type of the activity, a deposit or a loan. Rogošic et al. (2012) wrote that larger banks, as opposed to medium-sized and small banks in the Republic of Croatia, publish more data on socially responsible business. Also, large banks in Croatia publish less information on socially responsible business than their parent banks abroad. In Croatia, those are mostly information about special products for the development of the local community, new products, donations for art and culture, health and sports projects and special services they offer to their clients. On the other hand, there is a deficit of information on workplace safety and protection; awards won for the products and investments in ecological projects (like more favourable loans). Out of the total six areas of reporting on socially responsible business, banks mostly publish activities in the area of participation in the life of the local community.

For the purpose of researching reputation and socially responsible business, Kundid (2012) suggests a systematization of measuring socially responsible business i.e. the use of an index that includes: ethical code, community (philanthropic activities, sponsorships, scholarships), reporting on social responsibility, aspects of environmental protection, financial inclusion and cooperation with the institutions that promote socially responsible business and in his research, the author includes: Zagrebačka banka, Privredna banka, Erste, Raiffeisen, Hypo Alpe Adria Bank, Societe Generale Splitska banka, Hrvatska poštanska banka, OTP and Sberbanka. The findings have shown that the importance of reporting on socially responsible business has been growing, and the above-listed banks have, on average published information for more than half the activities that are comprised in the index.

In this paper, based on the publicly available data, the practice of social responsibility by Erste Steirmerkische and Hrvatska poštanska banka has been investigated. Internal and external dimensions of socially responsible business of the selected banks in Croatia have been observed.

Erste banka has a long tradition of socially responsible business marked with donations for cultural, sporting, educational and humanitarian manifestations throughout the country, taking into account regional and local specificities. Within the framework of the internal dimension, efforts are made for ensuring a good working environment, the funds for the education of the employees, and the use of preventive medical services. Furthermore, Erste banka is famous for its project of corporative 
volunteering that has since 2011 become a part of the program for training the managers, and it enables employees to engage in helping the needy through their work. Also, in 2015, a fund-raising event Erste pomagalica was held, where the bank gave a charity donation for every drawing made by the children of its employees. Regarding the external dimension, the bank offers possibilities of cheaper products for target groups, micro-financing for best business ideas, investment loans for employment and education for its clients and special attention is given to the arrangement and organization of its offices for the clients with special needs. Furthermore, the bank has organized and/or participated in a series of donations and sponsorships: SOS dječje selo Hrvatska (homes for abandoned children), Klinika za dječje bolesti Zagreb (a children's clinic), Psihijatrijska bolnica Rab (a psychiatric hospital), Udruga "Crveni nosevi" (an association helping sick children and elderly), Centar za rehabilitaciju Zagreb (a rehabilitation centre), several sports clubs and cultural events, the PET Project and Korak $u$ život (a long-term humanitarian project that helps educate children without the appropriate parental care). Regarding environmental protection, the bank has offered green loans for ecological projects of their clients and pays much attention to paper recycling, green lighting, and airconditioning.

Hrvatska poštanska banka (HPB) is also aware of its activities within the community, and it has developed socially responsible business through several segments: care for the environment, investment in the training and development of its employees, donations and sponsorships. Their activities of a socially responsible business surpass the prescribed regulative, and the intention is to create an image that contributes to the general well-being of the society. Since 2007, HPB is a member of the UN Global Compact Initiative and reports on its progress in the segment of socially responsible business annually, highlighting anti-corruption principles, human rights, working conditions, and environmental protection. The internal dimension of socially responsible business is recognized through a project initiated by the employees who have answered the cry for help made by the home for abandoned children in Vugrovec. Moreover, HPB has adopted the recommendations by the UN for reducing waste, recycling, and rational use of office supplies and energy. The external dimension of socially responsible business is evident in the efforts made by HPB to support educational and scientific projects: HPB kombinacija diplomac (special loans and services for students), Stipendije Vukovarskih studenata (scholarships for students from Vukovar), donations to Nacionalna zaklada za potporu učeničkom i studentskom standard (a foundation helping students), health, sports, and cultural institutions and humanitarian organizations. Some of the most successful project have been: Zaklada "Vaša pošta" - a foundation that offers financial aid to abandoned children, financial support from the organizational board of Sinjska alka, Kupujmo hrvatsko (a project supporting Croatian products), Bijenale slikarstva (supporting the Croatian Association of Artists), Modni ormar (an event supporting the fashion students) and the projects for education of the citizens and entrepreneurs.

It can be assumed that in future, as the awareness of the clients grows, especially in the conditions of long-term crisis and the above-average profitability of the banks, socially responsible business practices will grow as well (Kundid et al., 2011).

As quoted in Sičenica (2001), Ardrey et al. say that researches have proved that long-term positive publicity can create credibility and trust in financial institutions.

\section{Conclusion}

As research has shown long term competitive advantage of banks is usually internally generated, with banks finding sources of their competitiveness in, for them, unique, 
specific, and valuable resources that are hard to imitate. As one of these resources, reputation has an important role for banks and can be seen as a significant determinant of their market success and competitiveness. Good bank reputation is critical for banks as of its potential in creating additional value, and customer loyalty, but also as it is hard to be replicated by competitors. Banks offer intangible services and products, and as of inseparability of production and consumption, customers put greater emphasis on bank reputation. Among others, reputation is built on the quality of products and services, but, as emphasized by several researchers, also by corporate social responsibility that creates a positive image and reputation in the eyes of stakeholders.

In this paper, we present the concept of reputation, with special emphasis on the role and antecedents of a reputation for banks. Furthermore, we provide an overview of the existing research regarding the reputation of banks in Croatia and specifically analyse CSR as an important aspect of bank activities. By providing a descriptive analysis of CSR activities of two banks, we aim to provide an insight into their reputation building activities. Future research, still, should address the issue more thoroughly, by encompassing a wider number of banks in Croatia, and analyse more empirically and quantitatively the antecedents and consequences of bank reputation for banks in Croatia.

\section{References}

1. Andaleeb, S. S., Anwar, S. F. (1996), "Factors influencing customer trust in salespersons in a developing country", Journal of International Marketing, Vol. 4, No. 4, pp. 35-52.

2. Balabanis, G., Phillips, H. C., Lyall, J. (1998), "Corporate social responsibility and economic performance in the top British companies: are they linked?", European Business Review, Vol. 98, No. 1, pp. 25-44.

3. Barnett, M. L., Jermier, J. M., Lafferty, B. A. (2006), "Corporate reputation: The definitional landscape", Corporate Reputation Review, Vol. 9, No. 1, pp. 26-38.

4. Brammer, S. J., Pavelin, S. (2006), "Corporate Reputation and Social Performance: The Importance of Fit", Journal of Management Studies, Vol. 43, No. 3, pp. 435-455.

5. Brown, B., Longsdon, J. M. (1997), "Factors Influencing Fortune's Corporate Reputation For 'Community and Environmental Responsibility'", in the Proceedings of the 8th Annual Meeting of the International Association for Business and Society, Destin, FL, USA, pp. 361-372.

6. Brown, T. J., Dacin, P. A., Pratt, M. G., Whetten, D. A. (2006), "Identity, intended image, construed image, and reputation: An interdisciplinary framework and suggested terminology", Journal of the Academy of Marketing Science, Vol. 34, No. 2, pp. 99-106.

7. Bushman, R. M., Wittenberg-Moerman, R. (2012), "The role of bank reputation in certifying future performance implications of borrowers' accounting numbers", Journal of Accounting Research, Vol. 50, No. 4, pp. 883-930.

8. Carlucci, D., Ferreira, F. A. F., Schiuma, G., Jalali, M. S., Antonio, N. J. S. (2018), "Holistic conception of sustainable banking: adding value with fuzzy cognitive mapping", Technological and Economic Development of Economy, Vol. 24, No. 4, pp. 1303-1322.

9. Carmeli, A., Cohen A. (2001), "Organizational Reputation as a Source of Sustainable Competitive Advantage and Above-Normal Performance: An Empirical Test among Local Authorities in Israel", Public Administration \& Management: An Interactive Journal, Vol. 6, No. 4, pp. 122-165.

10. Chernev, A., Blair, S. (2015), "Doing well by doing good: The benevolent halo of corporate social responsibility", Journal of Consumer Research, Vol. 41, No. 6, pp. 1412 1425.

11. Corley, K. G., Harquail, C. V., Pratt, M. G., Glynn, M. A., Fiol, C. M., Hatch, M. J. (2006), "Guiding organizational identity through aged adolescence", Journal of Management Inquiry, Vol. 15, No. 2, pp. 85-99. 
12. Davies, G., Chun, R., Vinhas da Silva, R., Roper, S. (2003), Corporate reputation and competitiveness, London, Routledge.

13. Dell'Atti, S., Trotta, A., lannuzzi, A. P., Demaria, F. (2017), "Corporate social responsibility engagement as a determinant of bank reputation: An empirical analysis", Corporate Social Responsibility and Environmental Management, Vol. 24, No. 6, pp. 589-605.

14. Devlin, J., Ennew, C. (1997), "Understanding competitive advantage in retail financial services", International Journal of Bank Marketing, Vol. 15, No. 3, pp. 73-82.

15. Doorley, J., Garcia, H. F. (2006), Reputation Management: The Key to Successful Public Relations and Corporate Communication, Routledge, New York.

16. Doorley, J., Garcia, H. F. (2015), "Reputation Management", in Doorley, J., Garcia, H. F. (Eds.), Reputation Management - The Key to Successful Public Relations and Corporate Communication, 3rd edition, Routledge, San Francisco and London, pp. 45-48.

17. Flanagan, D. J., O'Shaughnessy, K. C. (2005), "The effect of layoffs on firm reputation", Journal of Management, Vol. 31, No. 3, pp. 445-463.

18. Fombrun, C. J. (1996), Reputation: realizing value from the corporate image, Harvard Business School Press, Boston.

19. Fombrun, C. J. (2001), "Corporate reputations as economic asset", in Hitt, M., Freeman, E. R., Harisson, S. J. (Eds.), The Blackwell Handbook of Strategic Management, Blackwell Publishers, Oxford, pp. 289-312.

20. Fombrun, C. J., Riel, C. B. M. (1997), "The reputational landscape", Corporate reputation review, Vol. 1, No. 1-2, pp. 1-16.

21. Fombrun, C. J., van Riel, C. B. M. (2004), Fame and Fortune: How Successful Companie Build Winning Reputations, Financial Times Prentice Hall, New Jersey.

22. Fombrun, C., Shanley, M. (1990), "What's in a name - reputation building and corporate-strategy", Academy of Management Journal, Vol. 33, No. 2, pp. 233-258.

23. Golin, A. (2003), Trust or Consequences: Build Trust Today or Lose Your Market Tomorow, AMACOM, New York.

24. Gray, E. R., Balmer, J. M. T. (1998), "Managing corporate image and corporate reputation", Journal of Long Range Planning, Vol. 31, No. 5, pp. 685-692.

25. Grgić, D. (2012), "Indeks reputacije poduzeća: empirijsko istraživanje u bankovnom sektoru", Market-Tržište, Vol. 24, No. 1, pp. 23-45.

26. Grunig, J. E., Hung, C. F. (2002), "The effect of relationships on reputation and reputation on relationships: a cognitive, behavioural study", Paper presented at PRSA Educator's Academy - 5th Annual International Interdisciplinary Public Relations Research Conference, Miami, FL.

27. Helm, S. (2011), "Corporate Reputation: An Introduction to a Complex Construct", in Helm, S., Liehr-Gobbers, K., Storck, C. (Eds.), Reputation Management, Springer, Heidelberg etc., pp. 3-16. http://erepository.vonbi.ac.ke:8080/xmlui/handle/123456789/23351 (21 June 2019). https://dash.harvard.edu/bitstream/handle/1/12534952/ioannou\%2Cserafeim theimpact-of-csr-on-investment-recommendations.pdf? sequence=1 (21 June 2019).

28. Ioannou, I., Serafeim, G. (2015), "The impact of corporate social responsibility on investment recommendations: analysts' perceptions and shifting institutional logics", available at:

29. Ivić, P., Grubišić, D. (2013), "Međuovisnost društveno odgovornog ponašanja i poslovne uspješnosti", Poslovna izvrsnost, Vol. 7, No. 2, pp. 83-101.

30. Jones, T. M. (1995), "Instrumental stakeholder theory: A synthesis of ethics and economics", Academy of Management Review, Vol. 20, No. 2, pp. 404-437.

31. Kasasbeh, E. A., Harada, Y., Noor, I. M. (2017), "Factors influencing competitive advantage in banking sector: a systematic literature review", Research Journal of Business Management, Vol. 11, pp. 67-73.

32. Krzakiewicz, K., Cyfert, S. (2015), "Organizational reputation risk management as a component of the dynamic capabilities management process", Management, Vol. 19, No. 1, pp. 6-18.

33. Kundid, A. (2012), "Društveno odgovorno poslovanje banaka u Republici Hrvatskoj", Ekonomska misao i praksa, No. 2, pp. 497-528. 
34. Kundid, A., Rogošić, A. (2011), "Bank online reporting: Comparative advantage, formalism of fashion?", Global Business \& Economics Anthology, Vol. 2, No. 2, pp. $500-$ 518.

35. Lee, K., Carter, S. (2009), Global Marketing Management, Oxford, Oxford University Press.

36. Lange, D., Lee, P. M., Dai, Y. (2011), "Organizational Reputation: A Review", Journal of Management, Vol. 37, No. 1, pp. 153-184.

37. Mahon, J. F. (2002), "Corporate Reputation: Research Agenda Using Strategy and Stakeholder Literature", Business \& Society, Vol. 41, No. 4, pp. 415-445.

38. McWilliams, A., Siegel, D. (2001), "Corporate social responsibility: A theory of the firm perspective", Academy of Management Review, Vol. 26, No. 1, pp. 117-127.

39. Nicolò, D. (2015), "Towards a theory on corporate reputation and survival of young firms", Procedia Economics and Finance, Vol. 22, pp. 296-303.

40. Nurn, C. W., Tan, G. (2010), "Obtaining Intangible And Tangible Benefits From Corporate Social Responsibility", International Review of Business Research Papers, Vol. 6. No. 4, pp. 360-371.

41. Orlitzky, M., Schmidt, F. L., Rynes, S. L. (2003), "Corporate social and financial performance: A meta-analysis", Organization Studies, Vol. 24, No. 3, pp. 403-441.

42. Phillips, D. (2006), "Relationships are the core value for organizations", Corporate Communications: An International Journal, Vol. 11, No. 1, pp. 34-42.

43. Redempta, O. M. (2008), "Sources of sustainable competitive advantage in the banking industry in Kenya", available at:

44. Reputation Institute (2018), available at: https://www.reputationinstitute.com/whyreputation-institute (7 August 2019).

45. Rhee, M., Haunschild, P. R. (2006), "The liability of good reputation: A study of product recalls in the U.S. automobile industry", Organizational Science, Vol. 17, No. 1, pp. 101117.

46. Rindova, V. P. (1997), "The image cascade and the formation of corporate reputations", Corporate Reputation Review, Vol. 1, No. 2, pp. 189-194.

47. Rindova, V. P., Fombrun, C. J. (1999), "Constructing Competitive Advantage: The Role of Firm-constituent Interactions", Strategic Management Journal, Vol. 20, No. 8, pp. 691710.

48. Rindova, V., Williamson, I. O., Petkova, A. P. (2010), "Reputation as an Intangible Asset: Reflections on Theory and Methods in Two Empirical Studies of Business School Reputations", Journal of Management, Vol. 36, No. 3, pp. 610-619.

49. Rindova, V. P., Williamson, I. O., Petkova, A. P., Sever, J. M. (2005), "Being good or being known: An empirical examination of the dimensions, antecedents, and consequences of organizational reputation", Academy of Management Journal, Vol. 48, No. 6, pp. 1033-1049.

50. Roberts, P. W., Dowling, G. R. (2002), "Corporate reputation and sustained superior financial performance", Strategic Management Journal, Vol. 23, No. 12, pp. 1077-1093.

51. Rogošić, A., Kundid, A. (2012), "Izvještavanje o društvenoj odgovornosti banaka U Hrvatskoj", Praktični menadžment : stručni časopis za teoriju i praksu menadžmenta, Vol. 3, No. 2, pp. 15-20.

52. Roy, M. K., Khan, S. H. (2013) "Study on private commercial banks in Bangladesh," ASA University Review, Vol. 7, No. 1, pp. 63-80.

53. Ruiz, B., Esteban, A., Gutiérrez, S. (2014), "Determinants of reputation of leading Spanish financial institutions among their customers in a context of economic crisis", BRQ Business Research Quarterly, Vol. 17, No. 4, pp. 259-278.

54. Ruiz, B., García, J. A., Revilla, A. J. (2016), "Antecedents and consequences of bank reputation: a comparison of the United Kingdom and Spain", International Marketing Review, Vol. 33, No. 6, pp. 781-805.

55. Saeidi, S. P., Sofian, S., Saeidi, P., Saeidi, S. P., Saaeidi, S. A. (2015), "How does corporate social responsibility contribute to firm financial performance? The mediating role of competitive advantage, reputation, and customer satisfaction", Journal of Business Research, Vol. 68, No. 2, pp. 341-350. 
56. Schultz, M., Moritsen, J., Gabrielsen, G. (2006), "Sticky reputation: Analyzing a ranking system", Corporate Reputation Review, Vol. 4, No. 1, pp. 24-41.

57. Shapiro, C. (1983), "Premiums for High Quality Products as Returns to Reputations", The Quarterly Journal of Economics, Vol. 98, No. 4, pp. 659-680.

58. Sičenica, B. (2001), "Uloga promocije u marketingu hrvatskih banaka", Ekonomski pregled, Vol. 52, No. 5-6, pp. 730-745.

59. Simcic Brønn, P. (2007), "Relationship outcomes as determinants of reputation", Corporate Communications: An International Journal, Vol. 12 No. 4, pp. 376-393.

60. Stigler, G. J. (1962), "Information in the labor market", Journal of Political Economy, Vol. 70, No. 5, pp. 94-105.

61. The Harris Poll (2018), "The reputations of the most visible companies", available at: https://theharrispoll.com/axios-harrispoll-100/ (9 August 2019).

62. Trček, D. (2018), Trust and Reputation Management Systems An e-Business Perspective, Springer, Heidelberg.

63. Trotta, A., Cavallaro, G. (2012), "Measuring corporate reputation: A framework for Italian banks", International Journal of Economics and Finance Studies, Vol. 4, No. 1, pp. 21-30.

64. Trotta, A., lannuzzi, A. P., Pacelli, V. (2016), "Reputation, Reputational Risk and Reputational Crisis in the Banking Industry: State of the Art and Concepts for Improvements", in Dell'Atti, S., Trotta, A. (Eds.), Managing Reputation in The Banking Industry - Theory and Practice, Springer, Heidelberg, pp. 3-32.

65. Wang, Y., LO, H. P., Hui, Y. V. (2003), "The antecedents of service quality and product quality and their influences on bank reputation: evidence from the banking industry in China", Managing Service Quality: An International Journal, Vol. 13, No. 1, pp. 72-83.

66. Wartick, S. L. (2002), "Measuring corporate reputation: Definition and data", Business \& Society, Vol. 41, No. 4, pp. 371-392.

67. Wu, M.-W., Shen, C.-H. (2013), "Corporate social responsibility in the banking industry: Motives and financial performance", Journal of Banking \& Finance, Vol. 37, No. 9, pp. 3529-3547.

68. Yang, S-U., Grunig, J. E. (2005), "Decomposing organizational reputation: the effects of organization public relationship outcomes on cognitive representations of organizations and evaluations of organizational performance", Journal of Communication Management, Vol. 9, No. 4, pp. 305-325.

69. Yunfang, F. (2007), "Adaptive Trust Management in MANET", in the Proceedings of the 2007 International Conference on Computational Intelligence and Security (CIS), Harbin, China, IEEE, pp. 804-808.

70. Zabala, I., Panadero, G., Gallardo, L. M., Amate, C. M., Sánchez-Galindo, M., Tena, I., Villalba, I. (2005), "Corporate Reputation in Professional Services Firms: 'Reputation Management Based on Intellectual Capital Management'", Corporate Reputation Review, Vol. 8, No. 1, pp. 59-71.

71. Živko, I., Kandžija, T. (2013), "Impact of financial crisis on banking sector stability in Republic Croatia", Poslovna Izvrsnost: znanstveni časopis za promicanje culture kvalitete i poslovne izvrsnosti, Vol. 7, No. 1, pp. 129-144. 


\section{About the authors}

Berislava Starešinić, Ph.D. is Director for Affluent Segment Development, Function of Affluent Clients, Retail group, Privredna banka Zagreb. Her research interests include the banking sector, organizational behaviour, banking reputation, and direct and digital channels. The author can be contacted at bstaresinic@pbz.hr.

Mislav Ante Omazić started to work at the Faculty of Economics and Business Zagreb as a Teaching Assistant at the Department of Organization and Management. Today he is Full Professor of the same institution where he teaches a variety of classes such as Corporate Social Responsibility, Business Ethics, Management, Project Management, and Change Management. He worked on various domestic and international projects for public, private, and civil society organizations. During his research work, professor Omazić has published a number of papers in professional and scientific journals home and abroad and is the author and editor of several books. The author can be contacted at momazic@efzg.hr.

Ana Aleksić, Ph.D., is an Assistant Professor at the Faculty of Economics and Business, University of Zagreb, Department of Organization and Management. Her research interests include various aspects of organizational behaviour, with a special emphasis on deviant workplace behaviour and organizational design. She is the author and coauthor of several book chapters and journal publications and actively participates as a consultant in a number of scientific and commercial projects. The author can be contacted at aaleksic@efzg.hr. 